\title{
ANALISIS PENGARUH KINERJA KEUANGAN BANK TERHADAP PERTUMBUHAN LABA (STUDI PADA BANK SWASTA DEVISA DI PASAR MODAL INDONESIA PERIODE 2013-2017)
}

\author{
Indah Kusumasari \\ indahkusumasari3@gmail.com \\ Universitas Ahmad Dahlan \\ Desta Rizky Kusuma \\ kusuma.desta@gmail.com \\ Universitas Ahmad Dahlan
}

\begin{abstract}
ABSTRAK
The purpose of this study is to prove the Influence of Bank's Financial Performance on Profit Growth (Study on Foreign Exchange Private Banks in the Indonesian Capital Market for 2013-2017). The data used in this study were obtained from the Publication of Foreign Exchange Private Bank Financial Reports published in Financial Services Orientation with period 2013-2017. The total population of this study was 44 companies and the number of samples was 21 companies through the purposive sampling stage. The data analysis technique in this study uses panel data multiple regression analysis. Based on hypothesis testing using Partial Test (t), it concluded that Capital Adequacy Ratio (CAR) and Loan to Deposit Ratio (LDR) had no effect on the Growth of Profit, while Non-Performing Loans (NPL) and Operational Costs and Operating Income (BOPO) ) negative effect on Profit Growth (Growth).
\end{abstract}

Kata Kunci: Capital Adequacy Ratio (CAR), Non Performing Loan (NPL), Operational Costs and Operating Income (BOPO), Loan to Deposit Ratio (LDR), Profit Growth (Growth).

\footnotetext{
PENDAHULUAN

Bank merupakan lembaga keuangan yang mempunyai fungsi menghimpun dana dari masyarakat, menyalurkan dana kepada masyarakat, dan memberikan pelayanan dalam bentuk jasa perbankan. Masyarakat mempercayai bahwa bank sebagai tempat yang aman untuk berinvestasi dan menyimpan dana (uang) dalam bentuk simpanan giro, tabungan, dan deposito. Dunia perbankan merupakan salah satu insitusi yang sangat berperan dalam bidang perekonomian suatu negara (khususnya di bidang pertumbuhan perekonomian) sebagai lembaga keuangan perbankan harus memiliki kinerja yang baik, karena dengan
}

kinerja yang baik bank akan dapat lebih mudah mendapatkan kepercayaan dari para nasabah (agent of trust).

Berdasarkan informasi dari situs www.bi.go.id sektor keuangan 2016 mengalami peningkatan dari ketahanan industri perbankan yang tetap terjaga didukung oleh permodalan yang kuat serta terjaganya risiko-risiko utama antara lain risiko kredit, risiko likuiditas dan risiko pasar. Ketahanan permodalan yang kuat ditunjukan oleh rasio kecukupan modal atau Capital Adequacy Ratio industri perbankan yang meningkat menjadi $22,69 \%$ pada 2016 , dari $21,16 \%$ di tahun sebelumnya. Berdasarkan intermediasi perbankan, pertumbuhan kredit industri perbankan mengalami perlambatan tetapi 
terdapat peningkatan pertumbuhan Data Pihak Ketiga menjadi 9,60\% dari 7,26\% di 2015. Peningkatan tersebut disebabkan penerimaan dana amnesti pajak oleh bank yang ditunjuk sehingga terjadi penurunan pada Loan To Deposit Ratio (LDR) perbankan. Kredit industri perbankan melambat ke $7,86 \%$ dari $10,45 \%$ di 2015 , karena rendahnya permintaan terhadap kredit baru, yang diikuti tingginya tingkat kehati-hatian bank dalam menyalurkan kredit. Sementara itu, rasio kredit bermasalah Non Performing loan tercatat sebesar 2,93\% meningkat dari 2,49\% pada tahun 2015. Risiko kredit tersebut terjadi pada sektor pertambangan, pengangkutan dan perdagangan.

\section{Rumusan Masalah}

1. Apakah Capital Adequacy Ratio (CAR) berpengaruh terhadap pertumbuhan laba?

2. Apakah Non Performing Loan (NPL) berpengaruh terhadap pertumbuhan laba?

3. Apakah Beban Operasional dan Pendapatan Operasional (BOPO) berpengaruh terhadap pertumbuhan laba?

4. Apakah Loan to Deposit Ratio (LDR) berpengaruh terhadap pertumbuhan laba?

\section{REVIEW LITERATUR DAN HIPOTESIS}

\section{Peran bank}

Taswan (2010:6), mengemukakan bahwa bank adalah sebuah Lembaga atau Perusahaan yang aktivitasnya menghimpun dana berupa giro, deposito tabungan dan simpanan yang lain dari pihak yang kelebihan dana (surplus spending unit) kemudian menempatkannya kembali kepada masyarakat yang membutuhkan dana (deficit spending unit) melalui penjualan jasa keuangan yang dapat meningkatkan kesejahteraan rakyat banyak. Sedangkan Perbankan adalah segala sesuatu yang berkaitan dengan bank, mencakup kelembagaan, kegiatan usaha, serta cara dan proses dalam melakasanakan kegiatan usahanya. Kegiatan usaha tersebut adalah menyangkut jasa keuangan.

\section{Kinerja Keuangan}

Kinerja keuangan perusahaan merupakan suatu gambaran mengenai kondisi perusahaan yang meliputi posisi keuangan serta hasil-hasil yang telah dicapai oleh perusahaan yang tercermin dalam laporan keuangan. Tinggi rendahnya kinerja suatu perusahaan merupakan dasar pertimbangan yang digunakan dalam pemilihan tujuan investasi oleh para investor pada umumnya.

\section{Penilaian Kinerja Bank}

Bahwa kinerja atau kemampuan bank dalam meningkatkan nilai usahanya melalui peningkatan laba, aset dan prospek kedepan yang dievaluasi dengan CAMEL (Capital, Asset, Management, Earning and Liquidity). Tingkat kesehatan bank ditetapkan melalui hasil penilaian kualitatif atas berbagai aspek yang berpengaruh terhadap kondisi atau kinerja bank melalui penilaian kuantitatif terhadap faktor CAMEL. Menurut Dendawiajaya (2009:121) mengemukakan bahwa kinerja bank dapat dilakukan dengan menggunakan rasio CAR, NPL, BOPO, dan LDR memperhitungkan Aktiva Tertimbang Menurut Risiko (ATMR) berdasarkan nilai masing-masing pos aktiva pada neraca bank dikalikan dengan bobot risikonya. Rumus CAR sebagai berikut (Dendawijaya, 2009:121) :

Penilaian kinerja keuangan dilakukan melalui analisis laporan keuangan, untuk itu diperlukan pengukuran kinerja perusahaan agar perusahaan dapat mengetahui pemanfaatan sumber daya yang dimiliki serta untuk mengetahui apakah perusahaan berkembang, bertahan, atau mengalami kegagalan. Untuk menilai kinerja keuangan dan prestasi perusahaan, 
analisis keuangan memerlukan tolak ukur yaitu rasio, yang menghubungkan dua data keuangan yang satu dengan yang lainnya. Kriteria terhadap penilaian kinerja bank ditetapkan dalam empat predikat tingkat penilaian sebagai berikut:

\begin{tabular}{|c|c|}
\multicolumn{2}{|c|}{ Tabel 2.1 Predikat Penilaian Bank } \\
\begin{tabular}{|c|c|}
\hline Nilai Kredit CAMEL & Predikat \\
\hline $81-100$ & Sehat \\
$66<81$ & Cukup Sehat \\
$51<66$ & Kurang Sehat \\
$0<51$ & Tidak Sehat \\
\hline
\end{tabular} \\
Sumber: Surat Edaran Bank Indonesia Nomor 6/23/DPNP 31 Mei 2004
\end{tabular}

Menurut Dendawiajaya (2009:121) mengemukakan bahwa kinerja bank dapat dilakukan dengan menggunakan rasio CAR, NPL, BOPO, dan LDR yang dapat diuraikan sebagai berikut:

\section{a. CAR (Capital Adequacy Ratio)}

CAR (Capital Adequacy Ratio) adalah kewajiban bank menyediakan modal minimal yang harus dimiliki oleh setiap bank umum. Berdasarkan ketentuan Bank Indonesia harus memiliki CAR paling sedikit sebesar $8 \%$. Sesuai dengan standar yang ditetapkan oleh BIS (Bank For International Settlements). Capital Adequacy Ratio merupakan rasio yang menunjukkan besarnya kecukupan modal yang dimiliki bank dalam menutupi aktiva yang berisiko. Sehingga tinggi rendahnya nilai CAR suatu bank, akan mempengaruhi kinerja dan kemampuan bank untuk melaksanakan kegiatan operasionalnya.

\section{b. NPL (Non Perfoming Loan)}

NPL (Non Perfoming Loan) merupakan rasio yang menunjukkan kemampuan manajemen bank dalam mengelola kredit bermasalah yang diberikan oleh bank. NPL dihitung berdasarkan perbandingan antara jumlah kredit yang bermasalah dibandingkan dengan total kredit. Rasio Non Perfoming Loan (NPL) menunjukkan bahwa kemampuan manajemen bank dalam mengelola kredit bermasalah yang diberikan oleh bank. Oleh sebab itu, jika semakin tinggi rasio ini maka akan semakin buruk kualitas kredit bank yang menyebabkan jumlah kredit bermasalah semakin besar maka kemungkinan suatu bank dalam kondisi bermasalah semakin besar.

c. BOPO (Beban Operasioanal dan Beban Pendapatan)

BOPO (Beban Operasional dan Beban Pendapatan) adalah perbandingan antara biaya operasional dan pendapatan operasional. Rasio BOPO digunakan untuk mengukur kemampuan pendapatan operasioanal dalam menutup biaya operasional. Jika kegiatan operasional dilakukan dengan efesien (nilai rasio BOPO rendah) maka pendapatan yang dihasilkan bank tersebut akan naik.Jika semakin tinggi BOPO semakin kurang efisien bank tersebut dalam mengendalikan biaya operasionalnya. Kurang efesien biaya, maka keuntungan (profit) yang diperoleh bank akan semakin menurun.

\section{d. LDR (Loan to Deposit Ratio)}

LDR (Loan to Deposit Ratio) adalah rasio antara seluruh jumlah kredityang diberikan bank dengan dana yang diterima oleh bank. Peraturan Bank Indonesia menyatakan bahwa kemampuan likuditas bank dengan Loan to Deposit Ratio (LDR) yaitu perbandingan antara kredit dengan Dana Pihak Ketiga (DPK). Standar LDR yang baik adalah $80 \%$. Oleh sebab itu pihak manaajemen harus dapat mengelola dana yang dihimpun dari masyarakat untuk kemudian disalurkan kembali dalam bentuk kredit. 


\section{Pertumbuhan Laba}

Laba adalah selisih pengukuran pendapatan dan biaya. Besar dan kecilnya laba sebagai pengukur kenaikan aktiva sangat tergantung pada ketepatan pengukuran pendapatan dan biaya. Sedangkan pertumbuhan laba adalah rasio yang menunjukkan kemampuan perusahaan meningkatkan laba bersih dibanding tahun sebelumnya. Dalam konsep dasar penyusunan dan penyajian laporan keuangan, income (penghasilan) adalah kenaikan manfaat ekonomi selama suatu periode akuntansi dalam bentuk pemasukan atau penambahan aktiva atau penurunan kewajiban yang mengakibatkan kenaikan ekuitas yang tidak berasal dari kontibusi penanaman modal.

\section{Penilitian Terdahulu}

Ulvah, dkk (2017), melakukan penelitian dengan judul "Pengaruh Tingkat Kesehatan Perbankan Terhadap Pertumbuhan Laba Pada Bank Umum Swasta Nasional Devisa Di Indonesia Periode 2012-2015". Tujuan dari penelitian tersebut untuk menganalisis pengaruh tingkat kesehatan perbankan dengan menggunakan NPL, LDR, PDN, BOPO, dan CAR terhadap pertumbuhan laba. Populasi yang digunakan dalam penelitian tersebut adalah bank umum swasta nasional devisa periode 2012-2015 dengan 33 sampel. Hasil penelitian menunjukkan bahwa NPL, LDR dan CAR tidak berpengaruh signifikan terhadap pertumbuhan laba, sedangkan rasio PDN dan BOPO berpengaruh signifikan terhadap pertumbuhan laba.

Aini (2015), melakukan penelitian dengan judul "Pengaruh CAR, NIM, LDR, NPL, BOPO, Dan Kualitas Aktiva Produktif Terhadap Pertumbuhan Laba Pada Perusahaan Perbankan Terdaftar Di Bursa Efek Indonesia Tahun 2009-2011”. Penelitian tersebut bertujuan untuk menguji pengaruh Capital Adequacy Ratio (CAR), Net Interest Margin (NIM), Loan to Deposit Ratio (LDR), Non Perfoming
Loan (NPL), Biaya Operasional dan Pendapatan Operasional (BOPO), dan Kualitas Aktiva Produktif (KAP) terhadap perubahan laba pada perusahaan perbankan yang terdaftar di Bursa Efek Indonesia tahun 2009-2011. Hasil penelitian tersebut menunjukan bahwa variabel CAR, LDR, dan NPL mempunyai pengaruh positif terhadap Perubahan Laba. Sedangkan variabel NIM, BOPO, dan KAP berpengaruh negatif terhadap Perubahan Laba.

Penelitian lain juga dilakukan oleh Hidayatullah, dan Roby (2015) dengan judul "Analisis Pengaruh Rasio CAMELS Terhadap Pertumbuhan Laba Pada Perusahaan Perbankan Yang Terdaftar Di Bursa Efek Indonesia". Penelitian tersebut bertujuan untuk menganalisis pengaruh metode CAMELS terhadap pertumbuhan laba pada perusahaan perbankan yang terdaftar di bursa efek Indonesia. Hasil penelitian tersebut menunjukkan bahwa variabel Capital Adequacy Ratio (CAR) berpengaruh positif, NPL berpengaruh negatif. Net Interest Margin (NIM) berpengaruh positif, Biaya Operasional dan Pendapatan Operasional (BOPO)24 berpengaruh negatif, LDR berpengaruh postif, Giro Wajib Minimum (GWM) berpengaruh positif terhadap Pertumbuhan Laba Bank.

\section{Hipotesis}

H1: CAR (Capital Adequacy Ratio) berpengaruh positif terhadap pertumbuhan laba.

H2 : Non Perfoming Loan (NPL) berpengaruh negatif terhadap pertumbuhan laba.

H3 : Beban Operasional dan Pendapatan Operasional (BOPO) berpengaruh negatif terhadap pertumbuhan laba.

H4: Loan to Deposit Ratio (LDR) berpengaruh positif terhadap pertumbuhan laba. 


\section{METODE PENELITIAN}

\section{Populasi dan Sampel}

Menurut Sugiyono

populasi adalah wilayah generalisasi yang terdiri dari obyek-obyek yang mempunyai kualitas karakteristik tertentu yang ditetapkan dalam penelitian untuk dapat dipelajari sehingga kemudian dapat ditarik untuk kesimpulannnya. Populasi yang di gunakan dalam penelitian ini adalah seluruh Bank Swasta Devisa di Indonesia periode 31 Desember 2013 sampai 31 Desember 2017. Yaitu sebanyak 44 bank.Sampel adalah sebagian dari populasi yang memiliki karakteristik yang relatif sama dan dianggap bisa mewakili populasi (Sugiyono, 2013:118). Sampel yang dilakukan dalam penelitian ini menggunakan purposive sampling yaitu pengambilan sampel berdasarkan ketentuan tertentu yang sesuai dengan tujuan penelitian.

\section{Jenis Sumber Data}

Jenis data yang digunakan dalam penelitian ini adalah data sekunder dengan data kuantitatif. Data tersebut dapat diambil melalui www.idx.co.id, www.bi.go.id, dan www.ojk.co.id yang disusun berdasarkan laporan keuangan tahunan dari Bank Swasta Devisa di Indonesia yang terdaftar di Bursa Efek Indonesia pada periode 31 Desember 2013 sampai 31 Desember 2017.

\section{Teknik Pengumpulan Data}

Teknik dalam penelitian ini menggunakan cara pengumpulan yang diperoleh dari teori yang relevan, dokumen-dokumen yang ada atau catatancatatan yang tersimpan, baik berupa catatan buku, surat kabar, artikel, dan lain sebagainya. data yang diambil melalui website Bursa Efek Indonesia yaitu www.idx.co.id, website Bank Indonesia yaitu www.bi.go.id dan situs Orientasi Jasa Keuangan www.ojk.co.id

\section{Definisi Operasional Varibel Dependen (Y)}

Variabel Dependen (Y) atau Terikat Variabel dependen atau terikat adalah variabel yang dipengaruhi atau menajadi akibat dari variabel independent. Variabel dependen dalam penelitian ini adalah Pertumbuhan Laba (Y). Pertumbuhan Laba berarti terjadi kenaikan laba atau keuntungan semakin tinggi menunjukkan bahwa kinerja manajemen perbankan semakin baik. Rumus pertumbuhan laba sebagai berikut:

Pertumbuhan Laba $=\frac{\text { Laba Sekarang-Laba Sebelum }}{\text { Laba Sebelum }}$

\section{Variabel Independen $(\mathrm{X})$}

Variabel Independen (X) atau Bebas dalam penelitian ini terdiri dari:

\section{a. Capital Adequacy Ratio (CAR)} Capital Adequacy Ratio (CAR) adalah rasio kinerja bank untuk mengukur kecukupan modal yang dimiliki bank untuk menunjang aktiva yang mengandung atau menghasilkan risiko, misalnya kredit yang diberikan. Rasio ini juga memperhitungkan Aktiva Tertimbang Menurut Risiko (ATMR) berdasarkan nilai masing-masing pos aktiva pada neraca bank dikalikan dengan bobot risikonya. Rumus CAR sebagai berikut (Dendawijaya, 2009:121) :

$C A R=\frac{\text { Modal Bank }}{\text { Aktiva Tertimbang Menurut Risiko }}$

b. Non Perfoming Loan (NPL)

Non Perfoming Loan (NPL) adalah rasio yang digunakan untuk mengukur kemampuan manajemen bank dalam mengelola kredit bermasalah yang diberikan oleh bank. Kredit bermasalah yaitu risiko yang dikaitkan dengan kemungkinan kegagalan klien membayar kewajibannya atau risiko dimana debitur tidak dapat melunasi hutangnnya. NPL mencerminkan risiko kredit, semakin kecil NPL semakin kecil risiko yang ditanggung 
pihak bank. Bank Indonesia menetapkan kriteria rasio NPL di bawah 5\% (Aini, 2013). Rumus NPL sebagai berikut:

$$
\begin{aligned}
N P L & =\frac{\text { Kredit Bermasalah }}{\text { Total Kredit }} \\
\text { c. Beban Operasional dan } & \text { Pendapatan Operasional (BOPO) }
\end{aligned}
$$

Beban Operasional adalah semua biaya yang berhubungan dengan kegiatan usaha. Sedangkan, pendapatan Operasional adalah semua pendapatan yang merupakan hasil langsung dari kegiatan usaha bank yang benar-benar telah diterima (Dendawijaya, 2009:119). Rumus Bopo adalah sebagai berikut:

$B O P O=\frac{\text { Biaya (Beban) Operasional }}{\text { Pendapatan Operasional }}$

\section{d. Loan to Deposit Ratio (LDR)}

Loan to Deposit Ratio (LDR) adalah rasio antara seluruh jumlah kredit yang diberikan bank dengan dana yang diterima oleh bank (Dendawijaya, 2009:116). Rumus LDR adalah sebagai berikut:

$$
L D R=\frac{\text { Jumlah Kredit yang Diberikan }}{\text { Total Dana Pihak Ketiga }}
$$

\section{Uji Instrumen}

\section{Statistik Deskriptif}

Statistik deskirptif adalah statistika yang digunakan untuk menganalisis data dengan cara mendeskripsikan data yang telah terkumpul tanpa bermaksud untuk membuat kesimpualan yang berlaku umum. Statistika deskriptif meliputi penyediaan data dalam bentuk tabel-tabel mengenai perhitungan mean, standar deviasi, nialia minimum dan maksimum.

Teknik analis data yang digunakan untuk mengetahui pegaruh Capital Adequacy Ratio (CAR), Non Perfoming Loan (NPL), Beban Operasional dan Pendapatan Operasional (BOPO), Loan to Deposit Ratio (LDR) terhadap pertumbuhan laba pada bank. Data panel yang digunakan yaitu data panel model analisis ekonometrika dengan rumus:

$$
\text { Growth } h_{(i, t)}=a_{(i, t)}+b_{1} C A R_{(i, j)}+b_{2} N P L_{(i, t)}+b_{3} B O P 0_{(i, t)}+b_{4} L D R_{(i, t)}+e_{(i, t)}
$$

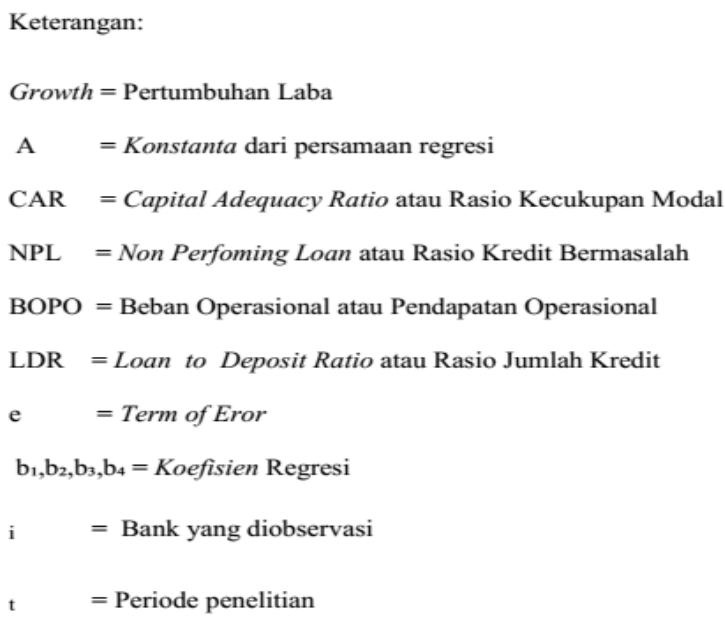

\section{a. Uji Normalitas}

Uji normalitas bertujuan untuk membuktikan bahwa data yang dipergunakan berdistribusi normal. Model regresi yang baik adalah distribusi data normal atau mendekati normal (Thoifah, 2015). Uji normalitas menggunakan uji Jarque-Bera dengan menggunakan bantuan progam statistik. Dasar pengambilan keputusan jika probibalitas lebih besar atau sama dengan nilai alpha yang ditentukan, yaitu 5\%, maka data dikatakan berdistribusi normal, dan sebaliknya jika probibalitas kurang 5\% maka data berdistribusi tidak normal.

\section{b. Uji Autokorelasi}

Uji Autokorelasi merupakan korelasi serangkaian observasi pada data yang bersifat runtut waktu (time series) atau dimungkinkan terjadinya pada antar objek (cross section). Autokorelasi dapat berbentuk positif dan negatif. Identifikasi Autokorelasi dilakukan dengan metode:

- Uji Breusch Godfrey atau uji BG

Uji ini dapat digunakan untuk menutupi kelemahan apada uji Durbin Watson ketika memberikan hasil "tidak ada kesimpulan”. Pengambilan 
keputusan dapat dilakukan sebagai berikut:

1. Prob. Chi Square > 0,05 : tidak ada autokorelasi

2. Prob. Chi Square < 0,05 : terjadi autokorelasi

\section{c. Uji Heteroskedastisitas}

Pengujian asumsi klasik yang keempat adalah uji heteroskedastisitas (heteriosccdasticity). Pengujian ini bertujuan untuk mengetahui ada tidaknya heteroskedastisitas, dalam hal ini akan dilakukan dengan menggunakan uji statistic, yaitu uji white, Uji ini menggunakan residual kuadrat variabel dependen dan independennya terdiri atas variabel independen yang sudah ada, ditambah dengan kuadrat variabel independen, ditambah dengan perkalian dua variabel independen. Pengambila keputusan dengan menggunakan program Eviews adalah sebagai berikut

1. Prob. chi square (p-value) $>0,05$ tidak terjadi heteroskedastisitas

2. Prob. chi square (p- value) $<0,05$ terjadi heteroskedastisitas.

\section{e. Uji Multikolinearitas}

Uji Multikolinearitas merupakan salah satu masalah dalam analisis regresi dengan OLS, yang berarti terdapat korelasi atau hubungan yang sangat tinggi diantara variabel variabel independen.

\section{Teknik Analisis Data}

Teknik analisis data yang digunakan dalam penelitian adalah analisis regresi data panel. Model analisis regresi data panel digunakan untuk mengolah data gabungan yang terdiri dari data silang (cross section) dan data runtut waktu (time series).

\section{Model Analisis Data Panel}

Setelah melakukan uji asumsi klasik perlu dilakukan pemilihan model yang akan digunakan dalam analisis data. Pemilihan model tersebut bertujuan untuk menganalisis data panel. Secara umum ada tiga model data panel yang sering digunakan yaitu model Common Effect, Fixed Effect, dan Random Effect.

\section{a. Common Effect}

Common Effect adalah Estimasi data panel hanya dengan mengkombinasikan data time series dan cross section dengan menggunakan metode OLS (Ordinary Least squares). Dalam pendeketan ini tidak memperhatiakan dimensi individu atau waktu.

\section{b. Fixed Effect}

Fixed Effect adalah teknik mengestimasi data panel dengan menggunakan variabel dummy untuk menangkap adanya perbedaan intersep. Adanya perbedaan intersep antara perusahaan namun intersepnya sama antar waktu. Sehingga, mengasumsikan bahwa koefisien regresi (slope) tetap antar perusahaan dan antar waktu (Agus, 2009:233).

\section{c. Random Effect}

Estimasi data panel dengan menggunakan residual yang diduga memiliki hubungan antar waktu dan antar individu. Model ini mengasumsikan bahwa setiap variabel mempunyaiperbedaan intersep, dan intersep tersebut bersifat random.

\section{Uji Parsial (T)}

Uji parsial (uji statistik T) digunakan untuk mengetahuipengaruh dari masing-masing variabel independen terhadap variabel dependen. Kriteria dalam uji $\mathrm{T}$ ini adalah sebagai berikut :

- Jika nilai koefisien menunjukkan positif, maka variabel independen berpengaruh positif terhadap variabel dependen.

- Jika nilai koefisien menunjukkan negatif, maka variabel independen berpengaruh negatif terhadap variabel dependen. 


\section{Uji Simultan (f)}

Uji ini dilakukan yaitu untuk mengatahui variabel independen secara simultan berpengaruh terhadap variabel dependen. Uji ini dilakukan yaitu dengan sig $<\alpha(0,05)$ yang artinya menerima $\mathrm{Ha}$ atau dengan kata lain variabel independen berpengaruh secara simultan terhadap variabel dependen dan jika nilai sig $>\alpha$ $(0,05)$ maka artinya hipotesis ditolak yang artinya menerima $\mathrm{H} 0$.

\section{Uji Koefisien Determinasi (R2)}

Uji ini digunakan untuk mengukur seberapa jauh kemampuan model regresi dalam menjelaskan variasi variabel dependen (Ghozali, 2011). Nilai koefisien determinasi besarnya antara 0 (nol) dan 1 (satu). Apabila nilai R2 mendekati 0, maka kemampuan variabel independen dalam menjelaskan variabel dependen masih terbatas. Sebaliknya, jika nilai R2 mendekati 1, maka kemampuan variabel independen dalam menjelaskan variabel dependen cukup baik.

\section{HASIL PENELITIAN DAN PEMBAHASAN}

\section{Hasil Penelitian}

\section{Statistik Deskriptif}

Tabel 4.6. Deskripsi Data Setelah Penyesuaiaan
\begin{tabular}{|l|r|r|r|r|r|}
\hline & Growth & \multicolumn{1}{l}{ CAR } & NPL & \multicolumn{1}{l|}{ BOPO } & \multicolumn{1}{l|}{ LDR } \\
\hline Mean & -0.088 & 0.188 & 0.021 & 0.850 & 0.837 \\
\hline Median & -0.080 & 0.176 & 0.020 & 0.861 & 0.855 \\
\hline Maximum & 1.267 & 0.352 & 0.061 & 1.008 & 1.133 \\
\hline Minimum & -1.113 & 0.104 & 0.000 & 0.541 & 0.506 \\
\hline Std. Dev. & 0.495 & 0.046 & 0.013 & 0.096 & 0.117 \\
\hline Skewness & 0.095 & 1.391 & 0.666 & -1.079 & -0.669 \\
\hline Kurtosis & 2.856 & 5.342 & 3.378 & 4.373 & 4.162 \\
\hline Jarque-Bera & 0.195 & 45.21 & 6.561 & 22.38 & 10.74 \\
\hline Probability & 0.906 & 0.000 & 0.037 & 0.000 & 0.004 \\
\hline Sum & -7.222 & 15.43 & 1.785 & 69.73 & 68.66 \\
\hline Sum Sq. Dev. & 19.89 & 0.175 & 0.013 & 0.758 & 1.119 \\
\hline \multicolumn{7}{|r|}{} & & & & & \\
\hline Observations & 82 & 82 & 82 & 82 & 82 \\
\hline
\end{tabular}
iumber: Data sekunder vang di olah

Setelah dilakukan penyesuaian data dengan scatter, terlihat bahwa jumlah sampel data menjadi 82 dan nilai probability mengalami perubahaan. Rasio CAR nilai probability adalah 0,000 kemudian nilai terendah (minimum) 0.104 dan yang tertinggi (maximum) adalah 0.352 kemudian rata-rata (mean) 0.188 . Rasio NPL nilai probability adalah 0.037 , diperoleh dengan data terendah 0.000 data tertinggi 0.061 dan rata-rata sebesar 0.021. Rasio BOPO nilai probability adalah 0.000 , diperoleh dengan data terendah 0.541 , data tertinggi 1.008 , dan rata-rata sebesar 0.850. Rasio LDR nilai probability adalah 0.004 diperoleh dengan data terendah 0.506 , data tertinggi 1.133 , dan rata-rata diperoleh sebesar 0.837 .

\section{Uji Asumsi Klasik}

\begin{tabular}{l} 
Tabel 4.7. Hasil Uji Asumsi Klasik \\
\begin{tabular}{|l|c|c|c|}
\hline Asumsi & Alat Uji & $\begin{array}{l}\text { Nilai } \\
\text { Prob. }\end{array}$ & Keterangan* \\
\hline Normalitas & Jarque-Bera & 0.292 & $\begin{array}{c}\text { Data berdistribusi } \\
\text { normal* }\end{array}$ \\
\hline $\begin{array}{l}\text { Autokorela } \\
\text { si }\end{array}$ & $\begin{array}{c}\text { Breusch-God } \\
\text { frey }\end{array}$ & 0.246 & $\begin{array}{c}\text { Tidak terjadi } \\
\text { autokorelasi* }\end{array}$ \\
\hline $\begin{array}{l}\text { Heterosked } \\
\text { asitas }\end{array}$ & $\begin{array}{c}\text { Breusch- } \\
\text { Pagan- } \\
\text { Godfrey }\end{array}$ & 0.053 & $\begin{array}{c}\text { Tidak terjadi } \\
\text { heteroskedasitas* }\end{array}$ \\
\hline
\end{tabular} \\
keterangan* Alpha yang digunakan $0.05(5 \%)$ \\
\hline
\end{tabular}

\section{a. Uji Normalitas}

Uji normalitas bertujuan untuk menguji apakah dalam model regresi, variabel residual memiliki distribusi normal. Dari hasil tabel 4.5 bahwa data dengan nilai Probability $0.292>0.05$, hal ini berarti bahwa data residual telah terdistribusi secara normal.

\section{b. Uji Autokorelasi}

Uji autokorelasi digunakan untuk mengetahui hubungan antara residual satu observasi dengan observasi lainnya. Setiap data residual pada suatu observasi diharapkan saling bebas dengan observasi lainnya atau tidak ada autokorelasi. Berdasarkan hasil uji Breusch-Godfrey (B-G) terlihat bahwa nilai Prob. Chi-Square sebesar 0.246 > 0.05 , sehingga dapat disimpulkan tidak terdapat masalah autokorelasi. 


\section{c. Uji Heteroskedastisitas}

Uji Heteroskedastisitas bertujuan untuk menguji apakah dalam model regresi terjadi ketidak samaan varian dari residual satu pengamatan ke pengamatan yang lain. Jika varian dari residual satu pengamatan kepengamatan yang lain tetap, maka disebut homokedastisitas dan jika berbeda akan disebut heteroskedastisitas. Dari hasil uji Breusch-PaganGodfrey (BPG) menunjukkan nilai prob. Chi-Square $0.053>0.05$, maka dapat disimpulkan tidak terjadi heteroskedastisitas.

\section{Uji Multikolineiritas}

\begin{tabular}{|c|c|c|c|c|}
\hline & CAR & NPL & BOPO & LDR \\
\hline CAR & 1 & -0.116 & -0.316 & 0.018 \\
\hline NPL & -0.116 & 1 & 0.553 & 0.045 \\
\hline BOPO & -0.316 & 0.553 & 1 & -0.066 \\
\hline LDR & 0.018 & 0.045 & -0.066 & 1 \\
\hline
\end{tabular}

Sumber: Data sekunder yang diolah

Berdasarkan hasil olah data bahwa nilai Nilai Koefisien < 90\%, maka dapat disimpulkan tidak terjadi multikolinearitas.

\section{Uji Regresi Data Panel}

Tabel 4.9. Hasil Estimasi Panel Model Common Effect

\begin{tabular}{|c|c|c|c|}
\hline Model Data Panel & Alat Uji & Nilai Prob. Chi Square & Keterangan \\
\hline Common Effect & Uji Chow & $0.385>0.05$ & Common Effect \\
\hline
\end{tabular}

Sumber: Data sekunder vang diolah

Berdasarkan pengujian yang dilakukan untuk pemilihan metode terbaik yang terpilih yaitu Common Effect (OLS) terlihat dari nilai prob. Chi square sebesar 0,385 > 0,05. Metode Common Effect (OLS) tersebut yang akan digunakan untuk mengestimasi persamaan. Pada tabel 4.8. disajikan hasil estimasi menggunakan metode Common Effect.

Tabel 4.10. Hasil Estimasi Persamaan Model Common Effect

\begin{tabular}{|c|c|c|c|c|}
\hline Variabel & $\begin{array}{c}\text { Nilai } \\
\text { Coefficient }\end{array}$ & Nilai t-Statistic & Nilai Prob. & $\begin{array}{l}\text { Nilai } R \text { - } \\
\text { Squared }\end{array}$ \\
\hline C & 1.647 & 2.326 & 0.022 & \multirow{5}{*}{0.222} \\
\hline CAR & -2.316 & -2.049 & 0.043 & \\
\hline NPL & -13.11 & -3.282 & 0.001 & \\
\hline BOPO & -1.080 & -1.892 & 0.062 & \\
\hline LDR & -0.114 & -0.268 & 0.789 & \\
\hline
\end{tabular}

Sumber: Data sekunder vang diolah
Hasil model regresi pada data panel dapat dituliskan:

Growth $=1.647_{(i, t)}-2.316 \mathrm{CAR}_{(i, t)}-13.11 \mathrm{NPL}(i, t)-1.080 \mathrm{BOPO}_{(i, t)}-0.114$

$\operatorname{LDR}_{(i, t)}+e_{(i, t)}$

\section{Uji Parsial (T)}

Uji Parsial (Uji t) dilakukan untuk menguji apakah setiap variabel bebas secara parsial atau terpisah mempunyai pengaruh yang signifikan secara parsial antara variabel CAR, NPL, BOPO, dan LDR terhadap Pertumbuhan Laba selama periode 2013-2017, yaitu dengan membandingkan thitung dengan ttabel. Nilai ttabel diperoleh dari melihat tabel df $=\mathrm{n}-\mathrm{k}$, yaitu dengan $\mathrm{n}=82$ dan $\mathrm{k}=4$. Dengan demikian dapat diperoleh $\mathrm{df}=82$ $4=78$, sehingga nilai $\mathrm{t}$ tabel yang diperoleh sebesar 1.664.

1. Pengaruh $\mathrm{Ca}$ pital Adequacy Ratio $(C A R)$ terhadap pertumbuhan laba Dari hasil perhitungan uji secara parsial diperoleh nilai thitung CAR sebesar $|2.049|>$ ttabel 1.664, sedangkan nilai koefisien regresinya sebesar 2.316 berarti setiap kenaikan CAR 1\% akan menurunkan Pertumbuhan Laba (Growth) sebesar 2.316\%. Dengan demikian hipotesis pertama menyatakan bahwa variabel CAR berpengaruh negatif terhadap Pertumbuhan Laba. Sedangkan hipotesis pada penelitian ini menyatakan bahwa CAR berpengaruh postif terhadap Pertumbuhan Laba. Sehingga H1 pada penelitian ini ditolak.

2. Pengaruh Non Perfoming Loan (NPL) terhadap pertumbuhan laba Dari hasil perhitungan uji secara parsial diperoleh nilai thitung - $|3.283|>$ ttabel 1.664, sedangkan nilai koefisien regresinya sebesar - 13.11 berarti setiap kenaikan NPL $1 \%$ akan menurunkan Pertumbuhan Laba (Growth) sebesar $13.11 \%$. Dengan demikian hipotesis kedua menyatakan bahwa NPL berpengaruh negatif terhadap Pertumbuhan Laba. Berdasarkankan hipotesis yang diajukan menerima $\mathrm{H}_{2}$. 
3. Pengaruh Beban Operasional dan Pendapatan Operasional (BOPO) terhadap pertumbuhan laba Dari hasil perhitungan uji secara parsial diperoleh nilai thitung - $|1.893|>$ ttabel 1.664 , sedangkan nilai koefisien regresinya sebesar - 1.080 berarti setiap kenaikan NPL $1 \%$ akan menurunkan Pertumbuhan Laba (Growth) sebesar $1.080 \%$. Dengan demikian hipotesis ketiga menyatakan bahwa BOPO berpengaruh negatif terhadap Pertumbuhan Laba. Berdasarkan hipotesis yang diajukkan menerima $\mathrm{H}_{3}$.

4. Pengaruh Loan to Deposit Ratio (LDR) terhadap pertumbuhan laba Dari hasil perhitungan uji secara parsial diperoleh nilai thitung - $|0.268|<$ ttabel 1.664, sedangkan nilai koefisien regresinya sebesar - 0.114 berarti setiap kenaikan LDR $1 \%$ akan menurunkan Pertumbuhan Laba (Growth) sebesar $0.114 \%$. Dengan demikian hipotesis keempat menyatakan bahwa bahwa Loan to Deposit Ratio (LDR) tidak berpengaruh terhadap pertumbuhan laba. Berdasarkan hipotesis yang diajukkan menolak $\mathrm{H}_{4}$.

\section{Uji Koefisien Determinasi $\left(\mathbf{R}^{2)}\right.$}

Koefisien determinasi $\left(\mathrm{R}^{2}\right)$ untuk mengukur seberapa jauh kemampuan model regresi dalam menerangkan variasi variabel dependennya. Nilai $\left(R^{2}\right)$ yang mendekati satu berarti variabel independennya hampir semua memberikan informasi yang dibutuhkan untuk memprediksi variasi variabel dependen.47 Dari hasil perhitungan nilai koefisien determinasi $\left(\mathrm{R}^{2}\right)$ diperoleh sebesar 0.222268 atau $22.22 \%$. Nilai tersebut menunjukkan bahwa kemampuan variabel CAR, NPL, BOPO, dan LDR mampu menjelaskan variasi variabel pertumbuhan laba sebesar $22.22 \%$ sedangkan sisanya sebsar $77.78 \%$ dijelaskan oleh variabel lain, selain variabel yang digunakan dalam penelitian ini.

\section{Pembahasan \\ Pengaruh Capital Adequacy Ratio (CAR) terhadap pertumbuhan laba}

CAR (Capital Adequacy Ratio) adalah rasio yang memperlihatkan seberapa besar jumlah seluruh aktiva bank yang mengandung risiko (kredit, penyertaan, surat berharga, tagihan pada bank lain) ikut dibiayai dari modal sendiri disamping memperoleh dana-dana dari sumbersumber diluar bank. CAR adalah modal sendiri yang tertimbang menurut risiko. Modal sendiri secara umum diperoleh dari common stock, walaupun modal sendiri dapat juga diperoleh dari retained earning. Menurut Pecking Order Theory, common stock merupakan sumber modal dengan biaya relatif lebih mahal dibandingkan dengan debt yang disebabkan oleh adanya flotation cost. CAR yang tinggi menunjukkan bahwa modal sendiri bank relatif lebih tinggi dibandingkan dengan CAR yang rendah. Meningkatnyajumlah modal sendiri yang secara umum dibiayai dari common stock akan mempunyai biaya modal yang lebih tinggi. Biaya modal yang tinggi akan menyebabkan laba yang diperoleh turun.

Bank yang dijadikan sampel dalam penelitian memiliki nilai rata-rata CAR yang tinggi yaitu $18.81 \%$. CAR yang tinggi dapat disebabkan karena bank kurang memanfaatkan modalnya untuk aktivitas-aktivitas yang menghasilkan laba, misalnya meningkat ekspansi kreditnya. Tingginya nilai CAR mengidentifikasikan bahwa bank kurang menempatkan aktivanya ke aktivitas-aktivitas yang mengandung risiko. Kurang optimalnya modal tersebut menyebabkan banyak kas yang menggangur dan tidak memberikan return yang memadai bahkan sebaliknya menimbulkan cost. Dengan adanya peraturan Bank Indonesia yang 
mewajibkan setiap bank harus memiliki modal atau tingkat rasio CAR minimal $8 \%$ mengakibatkan bank-bank selalu berusaha agar nilai CAR yang dimiliki sesuai dengan ketentuan tanpa mempertimbangkan pemanfaatan modal tersebut untuk aktivitas-aktivitas yang dapat menghasilkan laba, sehingga CAR berpengaruh negatif terhadap Pertumbuhan Laba.

Selain itu, nilai CAR signifikan dikarenakan Angka rasio CAR yang ditetapkan oleh Bank Indonesia adalah minimal $8 \%$, Jika rasio CAR sebuah bank berada dibawah $8 \%$ berarti bank tersebut tidak mampu menyerap kerugian yang mungkin timbul dari kegiatan usaha bank.

Kemudian jika rasio CAR diatas $8 \%$ dapat dilihat di tabel 4.5 menunjukkan bahwa nilai rata-rata (mean) $18.81 \%$, nilai ratarata tengah (median) $17.64 \%$, nilai maksimal (maximum) 35.20\%, nilai minimal (minimum) $10.43 \%$ maka bank tersebut semakin solvable. Dengan demikian, meningkatnya tingkat solvabilitas bank, maka secara tidak langsung akan berpengaruh pada meningkatnya kinerja bank, karena kerugian-kerugian yang ditanggung bank tidak dapat diserap oleh modal yang dimiliki bank tersebut.

Hasil penilitian ini tidak sesuai dengan penelitian yang dilakukakan oleh Aini (2015), bahwa CAR berpengaruh positif terhadap pertumbuhan laba.

\section{Pengaruh Non Perfoming Loan (NPL) terhadap pertumbuhan laba}

Hal ini berarti bahwa apabila suatu bank kondisi NPL tinggi maka akan memperbesar biaya, baik biaya pencadangan aktiva produktif maupun biaya lainnya, sehingga berpotensi terhadap kerugian bank dengan kata lain menurunkan pertumbuhan laba. Hasil penelitian ini sesuai dengan penilitian yang dilakukan oleh Ulvah, dkk (2017) dan

Hidayatullah, dan Roby (2015), bahwa Non Perfoming Loan (NPL) berpengaruh negatif terhadap pertumbuhan laba.

Rasio NPL menunjukkan kemampuan bank dalam mengelola kredit bermasalah yang diberikan oleh bank. Sehingga semakin tinggi rasio ini maka akan semakin buruk kualitas kredit bank yang menyebabkan jumlah kredit bermasalah semakin besar, Kemungkinan suatu bank dalam kondisi bermasalah semakin tinggi. Begitupun sebaliknya, semakin kecil NPL maka semakin kecil resiko kredit yang ditanggung bank.

\section{Pengaruh Beban Operasional dan Pendapatan Operasional (BOPO) terhadap pertumbuhan laba}

Semakin tinggi BOPO semakin kurang efisien bank tersebut dalam mengendalikan biaya operasionalnya. Kurang efesien biaya, maka keuntungan (profit) yang diperoleh bank akan semakin menurun. Semakin rendah rasio BOPO maka dapat meningkatkan pendapatan operasional pada bank. Sehingga berpengaruh negatif terhadap pertumbuhan laba. Hasil penelitian ini sesuai dengan penilitian yang dilakukan Aini (2015) bahwa BOPO berpengaruh negatif terhadap pertumbuhan laba.

\section{Pengaruh Loan to Deposit Ratio (LDR) terhadap pertumbuhan laba}

Loan to Deposit Ratio (LDR) tidak berpengaruh terhadap pertumbuhan laba yang berarti bahwa likiuiditas tidak memiliki kontribusi pada pertumbuhan laba Bank Swasta Devisa. Dapat dilihat dari tabel 4.5 bahwa data yang diperoleh nilai rata-rata $83.7 \%$ dan nilai rata tengah sebesar $85.5 \%$. Artinya data yang diperoleh dalam penelitian ini, pergerakan nilai LDR rata-rata variasi tidak banyak. 
Kenaikan hanya $1.8 \%$ sehingga dampak pengaruhnya tidak besar. Hal ini di karenakan kredit yang disalurkan oleh bank tidak banyak memberikan kontribusi laba karena terdapat pergerakan nilai LDR yang tidak banyak. Contohnya pada tahun 2013 LDR Bank Rakyat Indonesia Agroniaga hanya $87.1 \%$, Bank Central Asia 75.3\%, dan Bank Nusantara Parahyangan sebesar $84.4 \%$ di tahun yang sama. Pada tahun 2014 LDR Bank Rakyat Indonesia Agroniaga hanya 88.4\%, Bank Central Asia sebesar 76.7\%, dan Bank Nusantara Parahyangan $85.1 \%$. Jadi dari data tersebut terdapat bank-bank yang kurang mengoptimalkan dana pihak ketiga. Selain itu juga bias terjadi, karena kredit yang diberikan dipengaruhi tingkat kualitasnya.

Menurut Dendawijaya (2009:116), bahwa bank Indonesia menetapkan ketentuan rasio LDR sebesar $110 \%$ atau lebih, artinya likuiditas bank tersebut dinilai tidak sehat. Sebagian praktisi perbankan menyepakati bahwa batas aman dari LDR suatu bank adalah $80 \%$. Semakin tinggi LDR suatu bank tidak menjadi tolak ukur keberhasilan manajemen bank untuk memperoleh keuntungan yang tinggi. LDR yang tinggi tidak berpengaruh terhadap pertumbuhan laba, hal ini dapat dikarenakan besarnya pemberian kredit tidak didukung dengan kualitas kredit (kategori kredit macet dan kredit diragukan).

Kualitas kredit yang buruk akan meningkatkan risiko terutama bila pemberian kredit dilakukan dengan tidak menggunakan prinsip kehatihatian dan ekspansi dalam pemberian kredit yang kurang terkendali sehingga bank akan menanggung risiko yang lebih besar. Selain itu, LDR tidak signifikan karena adanya pergerakan data atau rasio LDR yang fluktuatif (tidak tetap) pada masingmasing perusahaan perbankan di setiap tahunnya. Ada perusahaan perbankan yang mempunyai nilai LDR rendah dan ada perusahaan perbankan yang mempunyai nilai LDR tinggi sehingga terjadi kesenjangan yang cukup tinggi antar perusahaan perbankan tiap tahunnya.

Hasil penelitian ini tidak sesuai dengan penilitian yang dilakukan oleh Aini (2015), dan Hidayatullah, dan Roby (2015), bahwa LDR (Loan to Deposit Ratio) berpengaruh positif terhadap pertumbuhan laba.

\section{KESIMPULAN DAN SARAN}

\section{Kesimpulan}

Penelitian ini mencoba untuk meneliti bagaimana pengaruh Capital Adequacy Ratio (CAR), Non Performing Loan (NPL), Biaya Operasional dan Pendapatan Operasional (BOPO), Loan to Deposit Ratio (LDR) terhadap Pertumbuhan Laba (Growth) sebagai proksi dari Kinerja Keuangan Perbankan pada Bank Swasta Devisa periode 20132017 yang tercatat di Bursa Efek Indonesia. Berdasarkan hasil analisis data dan pembahasan yang sudah

diuraikan dapat ditarik kesimpulan:

1. Capital Adequacy Ratio (CAR) berpengaruh negatif terhadap Pertumbuhan Laba (Growth). Hal ini membuktikan bahwa peran bank kurang memanfaatkan modalnya untuk aktivitas-aktivitas yang menghasilkan laba, misalnya meningkat ekspansi kreditnya. Kurang optimalnya modal tersebut menyebabkan banyak kas yang menggangur dan tidak memberikan return yang memadai bahkan sebaliknya menimbulkan cost. 
2. Non Performing Loan (NPL) berpengaruh negatif terhadap Pertumbuhan Laba (Growth). Rasio NPL menunjukkan kemampuan bank dalam mengelola kredit bermasalah yang diberikan oleh bank.. NPL tinggi maka akan memperbesar biaya, baik biaya pencadangan aktiva produktif maupun biaya lainnya, sehingga berpotensi terhadap kerugian bank dengan kata lain menurunkan pertumbuhan laba.

3. Biaya Operasional dan Pendapatan Operasional (BOPO) berpengaruh negatif terhadap Pertumbuhan Laba (Growth). Hal ini berarti Semakin tinggi BOPO semakin kurang efisien bank tersebut dalam mengendalikan biaya operasionalnya. Kurang efesien biaya, maka keuntungan (profit) yang diperoleh bank akan semakin menurun.

4. Loan to Deposit Ratio (LDR) tidak berpengaruh terhadap Pertumbuhan

Laba (Growth). Dengan demikian likiuiditas tidak memiliki kontribusi pada pertumbuhan laba Bank Swasta Devisa. Dalam penelitian ini, pergerakan nilai LDR rata-rata variasi tidak banyak. Kenaikan hanya $1.8 \%$ sehingga dampak pengaruhnya tidak besar. Hal ini di karenakan kredit yang disalurkan oleh bank tidak banyak memberikan kontribusi laba karena terdapat pergerakan nilai LDR yang tidak banyak.

\section{Saran}

Adapun saran-saran yang dapat diberikan melalui hasil penelitian ini adalah sebagai berikut:

\section{Bagi bank yang diteliti}

Hendaknya lebih memperhatikan nilai CAR, loans untuk menciptakan kredit yang tinggi dan diimbangi dengan kemampuan untuk memenuhi kredit tersebut, dengan berusaha menekan biaya operasioanal untuk meningkatkan efisiensi operasional perusahaan. Sehingga dapat merangsang Pertumbuhan Laba yang lebih optimal.

2. Bagi Peneliti Selanjutnya

Dari peneliti ini diketahui $22.22 \%$ merupakan pengaruh variabel lain diluar variabel yang diteliti. Penelitian selanjutnya disarankan dapat memperluas dengan menambahkan variabel lain yang belum diteliti.

\section{DAFTAR PUSTAKA}

Aini, Nur. 2015. "Pengaruh CAR, NIM, LDR, NPL, BOPO, dan Kualitas Aktiva Produktif Terhadap Perubahan Laba" Jurnal Akuntansi Keuangan dan Perbankan (Mei), Vol. 2, No. 1, hal. 14-25.

Aprilia, Ulvah Nathasya, Rahadian, Dadan, dan Anisah Firli. 2017. "Pengaruh Tingkat Kesehatan Perbankan Terhadap Pertumbuhan Laba Pada Bank Umum Swasta Nasional Devisa Di Indonesia Periode 2012 - 2015" Journal eProceeding of Management (Desember), Vol. 4, No. 3, hal. 2393.

Darmawi, Herman.2011. Manajemen Perbankan. Jakarta: Bumi Aksara.

Dendawijaya, Lukman. 2009. Manajemen Perbankan. Jakrta: Ghalia Indonesia.

Hidayatullah, dan Roby Febrianto. 2015. "Analisis Pengaruh Rasio CAMELS Terhadap Pertumbuhan Laba Pada Perusahaan Perbankan Yang Terdaftar Di Bursa Efek Indonesia" Journal Binus Business Review (November), Vol. 3, No. 2, hal. 614632.

https://www.ojk.go.id/id/kanal/perbankan/ data-dan statistik/laporankeuanganperbankan/ Def ault. aspx [15 September 2018] 
Kasmir. 2013. Bank Dan Lembaga

Keuangan Lainnya. Jakarta:

Rajagrafindo Persada.

Kasmir.2013. Manajemen Perbankan, Jakarta: Rajawali Pers.

Kasmir.2013. Pengantar Manajemen Keuangan. Jakarta: Kencana.

Koch, Timothy W and S.Scott MacDonald.2009. Bank

Management. 5 th

Edition.United State: Navta Associates, Inc.

Kusuma, Desta Rizky, dan Deny Ismanto. 2012. Modul Praktikum Eviews. Yogyakarta: UAD

Laporan Tahunan Annual Report, 2016, [Online] Didapatkan: https:

//www.bi.go.id/id/publikasi/laporantahunan/bi/Pages/LKTBI-2016.A spx [23 Maret 2018]

Munawir.S.2010. Analisis Laporan Keuangan.Edisi Keempat.Yogyakarta: Liberty.

Purwanti, dan D. Prawironegoro.2013. Akuntansi Manajemen. Edisi Ketiga. Jakarta:Mitra Wacana Media.57

Sugiyono.2013.Metode Penelitian Pendidikan. Bandung: Alfabeta.

Taswan. 2010. Manajemen Perbankan. Yogyakarta: UPP STIM YKPN.

Widarjono, Agus. 2009. Ekonometrika Pengantar dan Aplikasinya. Yogyakarta: EKONISIA 